\title{
Screening for cystic fibrosis in the newborn by meconium analysis
}

\author{
H. C. RYLEY, LYNNE M. NEALE, T. D. BROGAN, AND P. T. BRAY \\ Welsh National School of Medicine, Cardiff
}

SUMMARY During a 4-year routine screening programme for cystic fibrosis (CF) 15464 specimens were examined for raised meconium albumin levels by a test strip method and by electroimmunoassay. The incidence of false-positive results was about 5 per 1000 specimens in either test. This could be reduced by $90 \%$ by determining the ratio of albumin : $\alpha$-1-trypsin inhibitor (a ratio below 2.0 being considered as a negative result), and it could be reduced to zero by determining the ratio in subsequent faecal specimens. Three of 12 meconium specimens from infants with proved CF gave false-negative results in all 3 tests. The other 9 specimens had $>100 \mathrm{mg}$ albumin/g dry weight and albumin: $\alpha$-1-trypsin inhibitor ratios of $>3 \cdot 0$; in subsequent faecal specimens the ratios were over $4 \cdot 0$. 176 meconium specimens from elsewhere in the UK were examined and these included 23 from infants who were subsequently proved to have CF. Six of these 23 CF specimens gave false-negative results, the other 17 being strongly positive. The origins of meconium serum protein suggest that infants with CF in whom meconium gives false-negative results have normal pancreatic functions at birth. The specificity of current meconium tests therefore cannot be improved as they depend on pancreatic dysfunction.

The fact that the prognosis for infants with cystic fibrosis (CF) is improving is probably related to earlier diagnosis of the disease, thus enabling treatment to begin before the onset of irreversible pulmonary changes (Huang et al., 1970; Shwachman et al., 1970; Stern et al., 1976; Orenstein et al., 1977). With the exception of infants born with meconium ileus, the presence of CF in the newborn may not be suspected clinically for some time after birth and irreversible lung damage may have occurred (Warwick, 1969; Shwachman et al., 1970). There is therefore a case for mass neonatal screening for CF in those countries where the incidence of the disease is high.

Although the detection of raised concentrations of ions in the sweat is the most specific and accurate test for CF, for technical reasons this approach is not at present suitable for mass screening (Committee for a Study for Evaluation of Testing for Cystic Fibrosis, 1976). Most neonatal screening tests for CF thus depend on the detection of a raised albumin

Department of Medical Microbiology, Welsh National School of Medicine, Cardiff

H. C. RYLEY, senior scientific officer

LYNNE M. NEALE, technician

T. D. BROGAN, consultant pathologist

P. T. BRAY, consultant paediatrician content in meconium either by the semiquantitative test strip (Stephan et al., 1975) or by other immunochemical methods (Kollberg and Hellsing, 1975; Ryley et al., 1975; Schuttringer and Zinterhofer, 1978). The raised meconium albumin content most probably reflects a reduction in, or even absence of, pancreatic secretions containing proteolytic enzymes.

We report here the results from a 4-year study of CF screening by meconium analysis in which a comparison was made between the Boehringer Mannheim meconium test strip (BM-mec test) and the electroimmunoassay of albumin. The albumin: $\alpha$-1-trypsin inhibitor (alb: $\alpha-1-\mathrm{TI})$ ratio both in meconium and in subsequent faecal specimens was also assessed for its ability to improve the specificity of screening.

\section{Methods and materials}

Collection of meconium and faeces. Meconium specimens were collected daily from the maternity units of the University Hospital of Wales, Cardiff, from December 1973 to November 1977 and from St David's Hospital, Cardiff, from April 1975 to November 1977. During the 4-year period of the study, meconium specimens from home births were sent to the laboratory via the Community 
Midwives Unit. Analysis of 15464 specimens was carried out, of which 12 specimens were from infants with subsequently confirmed CF. Additional meconium specimens from 176 infants, 23 of whom were subsequently confirmed to have CF, were sent from other hospitals in the UK and were considered separately. Faecal specimens were analysed from 203 infants whose meconium gave a positive result with any test or from infants clinically suspected as having $\mathrm{CF}$.

Collection of cord sera and amniotic fluid. Cord sera matched with the infants' meconium specimens were obtained during a routine screening investigation into $\alpha$-1-trypsin inhibitor deficiency in the newborn. Amniotic fluid specimens were taken at the University Hospital of Wales, from each mother in whom the pregnancy was thought to carry a high risk of fetal abnormality. Specimens contaminated with blood or from babies in whom a congenital disorder was confirmed were not included in the results. All specimens were collected at an estimated gestation of 16-22 weeks.

Laboratory procedure for studying specimens. Meconium specimens were first tested with the BM mec-test (Boehringer Mannheim GmbH., Mannheim, Germany) and part of each specimen was transferred to a universal container for electroimmunoassay. A 4\% wet weight suspension of the specimen in $0.9 \%$ sodium chloride was prepared by homogenising the specimen in saline with the aid of a $19 \mathrm{~mm}$ diameter Teflon pestle (A. H. Thomas, Philadelphia, USA) driven by a stirring motor at $2000 \mathrm{rev} / \mathrm{min}$ (Baird and Tatlock, Essex, UK) for about 10 seconds. A $4 \%$ wet weight suspension was approximately equivalent to a $1 \%$ dry weight suspension previously used (Ryley et al., 1975). It was found unnecessary to remove the insoluble debris before analysing the protein content by electroimmunoassay. The rest of the specimen was freeze-dried and stored at $4^{\circ} \mathrm{C}$ for future reference. For purpose of comparison, albumin/g dry weight was estimated for all specimens in which albumin had been detected in the $4 \%$ wet weight suspension.

Faeces were not tested by the BM mec-test as the albumin content, even in specimens from infants with CF, was very low. On receipt of the specimen, a $16 \%$ wet weight suspension, approximately equivalent to a $4 \%$ dry weight suspension (Ryley et $a l ., 1976$ ), was prepared in saline. The suspension was homogenised in a sealed universal container by a vortex mixer. The alb: $\alpha-1-T I$ ratio was determined for all faecal specimens.

BM mec-test for protein in meconium. Specimens were tested with the BM mec-test and the results classified as negative, possible positive, or positive (Ryley et al., 1975).

Quantitative electroimmunoassay. Electroimmunoassay of albumin, $\alpha-1-T I$, and $\alpha-1-\mathrm{CI}$ in meconium and faeces was carried out as described (Ryley et al., 1975, 1976). Protein concentrations in undiluted amniotic fluid and cord sera, diluted 1:20 with barbitone buffer were also estimated by electroimmunoassay.

\section{Results}

Comparison of the BM mec-test and electroimmunoassay for albumin. Five infants per 1000 passed meconium specimens that gave a positive or a possible positive result. 34 infants per 1000 passed meconium that contained more than $1 \mathrm{mg}$ albumin/g dry weight and about 5 per 1000 specimens had values in excess of $20 \mathrm{mg} / \mathrm{g}$ dry weight. As over $20 \mathrm{mg}$ albumin $/ \mathrm{g}$ dry weight $(5 \mathrm{mg} / \mathrm{g}$ wet weight $)$ is usually taken as positive, the false-positive rate was similar in either test (Table 1).

When specimens from infants with CF were tested, 9 were positive and 3 negative in the BM mec-test. The 9 positive specimens all had levels in excess of $100 \mathrm{mg}$ albumin/g dry weight with a mean value of

Table 1 Comparison of BM test and albumin assay in meconium from normal and CF infants*

\begin{tabular}{|c|c|c|c|c|c|c|c|}
\hline & \multirow{2}{*}{$\begin{array}{l}B M \text { test } \\
\text { strip result }\end{array}$} & \multicolumn{5}{|c|}{ Albumin content $\mathrm{mg} / \mathrm{g}$ dry weight } & \\
\hline & & $<1.0$ & $1-4$ & $4-20$ & $20-50$ & $>50$ & \\
\hline \multicolumn{8}{|l|}{ Infants } \\
\hline \multirow[t]{4}{*}{ Free of CF } & - & 14948 & 212 & 186 & 24 & - & $15370(99.47 \%)$ \\
\hline & \pm & - & - & 28 & 19 & - & $47(0.30 \%)$ \\
\hline & + & - & - & 3 & 7 & 25 & $35(0.23 \%)$ \\
\hline & & $14948(96.74 \%)$ & $212(1 \cdot 37 \%)$ & $217(1.40 \%)$ & $50(0.32 \%)$ & $25(0 \cdot 16 \%)$ & 15452 \\
\hline \multirow[t]{4}{*}{ With CF } & - & 2 & - & 1 & - & - & 3 \\
\hline & \pm & - & - & - & - & 一 & - \\
\hline & + & 一 & 一 & - & 一 & 9 & 9 \\
\hline & & 2 & 一 & 1 & - & 9 & 12 \\
\hline
\end{tabular}

*Specimens routinely screened in Cardiff between November 1973 and October 1977. 
$313 \pm 145 \mathrm{mg} / \mathrm{g}$ dry weight $(110-490 \mathrm{mg} / \mathrm{g}$ dry weight). Two of the other 3 specimens had $<1 \mathrm{mg}$ albumin/g dry weight and the $3 \mathrm{rd}$ had $11 \mathrm{mg} / \mathrm{g}$ dry weight. Thus all 3 specimens gave false-negative results with both albumin tests (Table 1).

23 meconium specimens from infants with $\mathrm{CF}$ were also examined independently of the routine screening programme. 17 gave positive results with the BM mec-test and had $>50 \mathrm{mg}$ albumin/g dry weight with a mean value of $283 \pm 138 \mathrm{mg} / \mathrm{g}$ dry weight (range $78-510 \mathrm{mg} / \mathrm{g}$ dry weight). One specimen gave a possible positive result with the BM mec-test and had $34 \mathrm{mg}$ albumin/g dry weight. The other 5 specimens gave negative results with the BM mec-test and had 1.0-17.0 mg albumin/g dry weight.

Evaluation of the alb: $\alpha-1-T I$ ratio. An alb: $\alpha-1-T I$ ratio value was estimated for each specimen that contained $>4 \mathrm{mg}$ albumin/g dry weight and for each meconium specimen from an infant with $\mathrm{CF}$, irrespective of albumin content (Table 2). Wherever possible, the ratio was subsequently estimated for faeces. A value of 2.0 was taken as the borderline value between positive and negative results (Ryley et al., 1975). Two specimens contained $<20 \mathrm{mg}$ albumin/g dry weight but had ratios of over $2 \cdot 0$. One specimen was from an infant who died a few days after birth and was found at necropsy to have oesophageal atresia without a tracheo-oesophageal fistula. The other was from an infant previously described by us (Ryley et al., 1975) in whom the ratio had been artificially high because the mother had $\mathrm{ZZ} \alpha-1$-TI deficiency. 65 specimens from infants without CF had $>20 \mathrm{mg}$ albumin/g dry weight and 9 of these also had a ratio of over $2 \cdot 0$. However the alb: $\alpha-1-$ TI ratios in the subsequent faecal specimens were not higher than 0.2 in any of the 9 infants. Eight of the 9 were premature with estimated gestation ages of between 27 and 33 weeks, and the specimen from the 9th infant was contaminated with blood. 10 other specimens appeared to be contaminated with blood but in none was the ratio above $\mathbf{2} \cdot \mathbf{0}$.
The 9 positive meconium specimens from infants with CF all had ratios of $>2.0$ with a mean value of $8 \cdot 2 \pm 5 \cdot 3$ (range $3 \cdot 0-20 \cdot 0$ ). In all 7 follow-up faecal specimens, the ratio value was $>4 \cdot 0$. The 3 negative meconium specimens from infants with $\mathbf{C F}$ also had ratios of $<0 \cdot 2$; in follow-up studies, faeces from 2 infants gave ratios of $5 \cdot 1$ and $3 \cdot 5$. Faeces from the 3rd infant had a ratio of $<0.1$ but this child was receiving a pancreatic enzyme supplement to his diet.

18 specimens of meconium from CF infants outside the screening programme had $>20 \mathrm{mg}$ albumin/g dry weight and 17 had ratios $>2.0$ with a mean value of $7 \cdot 0 \pm 3.9$ (range $3 \cdot 0-16 \cdot 0$ ). The other specimen which had the lowest albumin content of the 18 (34 mg/g dry weight) had a ratio of $0 \cdot 3$.

Five specimens had a low albumin content, 4 had ratios of $<0.2$ and one, from an infant with meconium ileus, had a ratio of $2 \cdot 1$. In cases where follow-up studies on faeces were possible, all but one specimen had a ratio of $>2 \cdot 0$.

In addition to the above, 3 faecal specimens were obtained from infants with CF in whom the meconium had not been screened at birth and all 3 specimens had ratios $>3 \cdot 0$. Conversely no faecal specimen from infants in whom CF was initially suspected but not subsequently confirmed, gave ratios higher than $0 \cdot 15$.

False-negative results. Nine of the 35 meconium specimens from all infants with CF gave a falsenegative result in at least one of the 3 tests (Table 3). Specimens 1-7 gave a negative result with the BM mec-test, albumin assay, and alb: $\alpha-1-\mathrm{TI}$ ratio. Specimen 8 gave a borderline positive result with the test strip and albumin assay, but gave a negative ratio result. Specimen 9 gave negative test strip and albumin results, but a borderline positive ratio. CF was confirmed in Cases 1-8 by the infant having symptoms consistent with the disease and positive results to the sweat test. Case 9, born with meconium ileus, died soon after an operation; the diagnosis of

Table 2 Distribution of albumin: $\alpha$-1-trypsin inhibitor ratio in meconium and faecal specimens. Ratio estimation was carried out on specimens from normal infants where albumin content was greater than $4.0 \mathrm{mg} / \mathrm{g}$ dry weight

\begin{tabular}{|c|c|c|c|c|c|c|c|}
\hline & \multirow{2}{*}{$\begin{array}{l}\text { Albumin content } \\
\text { in meconium } \\
\text { specimen }\end{array}$} & \multicolumn{3}{|c|}{ Albumin: $\alpha-1$-trypsin inhibitor ratio in meconium } & \multicolumn{3}{|c|}{ Albumin: $\alpha-1$-trypsin inhibitor ratio in faeces } \\
\hline & & $<1 \cdot 0$ & $1 \cdot 0-2 \cdot 0$ & $>2 \cdot 0$ & $<1.0$ & $1 \cdot 0-2 \cdot 0$ & $>2 \cdot 0$ \\
\hline \multicolumn{8}{|l|}{ Infants } \\
\hline \multirow[t]{3}{*}{ Free of CF } & $4-20$ & 219 (1) & $6(4)$ & $2(1)$ & 6 & - & 一 \\
\hline & $20-50$ & 27 (3) & $7(3)$ & $6(6)$ & 12 & 一 & - \\
\hline & $>50$ & $12(3)$ & $10(4)$ & $3(3)$ & 10 & 一 & - \\
\hline \multirow[t]{3}{*}{ With CF } & 0-20 & $3(3)$ & 一 & - & 1 & 一 & 2 \\
\hline & $20-50$ & - & - & - & - & - & - \\
\hline & $>50$ & - & - & $9(7)$ & - & 一 & 7 \\
\hline
\end{tabular}

Figures in brackets indicate number in each group for whom follow-up faecal specimen was examined. 
Table 3 Data on CF infants who passed meconium that gave a false-negative result

\begin{tabular}{|c|c|c|c|c|c|c|c|c|}
\hline \multirow[t]{2}{*}{ Case } & \multirow{2}{*}{$\begin{array}{l}\text { Age at } \\
\text { diagnosis } \\
\text { (months) }\end{array}$} & \multirow{2}{*}{$\begin{array}{l}\text { Sibling of older } \\
\text { CF child }\end{array}$} & \multirow{2}{*}{$\begin{array}{l}\text { Sweat } C l \\
(\mathrm{mmol} / \mathrm{l})\end{array}$} & \multicolumn{3}{|l|}{ Meconium tests } & \multicolumn{2}{|l|}{ Faeces tests } \\
\hline & & & & $B M$ test strip & $\begin{array}{l}\text { Albumin mg/g } \\
\text { dry weight }\end{array}$ & $\begin{array}{l}\text { Albumin: } \\
\text { a-1-trypsin } \\
\text { inhibitor ratio }\end{array}$ & $\begin{array}{l}\text { Albumin } \mathrm{mg} / \mathrm{g} \\
\text { dry weight }\end{array}$ & $\begin{array}{l}\text { Albumin: } \\
\alpha-1-\text { trypsin } \\
\text { inhibitor ratio }\end{array}$ \\
\hline $\begin{array}{l}1 \\
2 \\
3 \\
4 \\
5 \\
6 \\
6 \\
7 \\
8 \\
9\end{array}$ & $\begin{array}{l}10 \\
3 \\
5 \\
3 \\
5 \\
9 \\
1 \cdot 5 \\
6 \\
1 \text { week }\end{array}$ & $\begin{array}{l}\text { No } \\
\text { Yes } \\
\text { Yes } \\
\text { No } \\
\text { Yes } \\
\text { No } \\
\text { Yes } \\
\text { Yes } \\
\text { No }\end{array}$ & $\begin{array}{r}110 \\
120 \\
100 \\
110 \\
90 \\
105 \\
120 \\
110\end{array}$ & $\begin{array}{l}- \\
- \\
- \\
- \\
\pm \\
\pm\end{array}$ & $\begin{array}{r}<1 \cdot 0 \\
8 \cdot 4 \\
17 \cdot 6 \\
10 \cdot 8 \\
1 \cdot 1 \\
<1 \cdot 0 \\
2 \cdot 6 \\
34 \\
11\end{array}$ & $\begin{array}{l}\overline{0.1} \\
0 \cdot 22 \\
0.17 \\
0.01 \\
\overline{0.02} \\
0.3 \\
2.1\end{array}$ & $\begin{array}{r}5 \cdot 0 \\
5 \cdot 0 \\
4 \cdot 3 \\
17 \cdot 6 \\
12 \cdot 0 \\
<0 \cdot 1 \\
1 \cdot 2 \quad \text { Not d } \\
\quad \text { Not d }\end{array}$ & $\begin{array}{r}3 \cdot 6 \\
5 \cdot 0 \\
4 \cdot 0 \\
13 \cdot 2 \\
15 \cdot 0 \\
1 \cdot 7 \\
\\
\end{array}$ \\
\hline
\end{tabular}

*Diagnosis of CF made on evidence of meconium ileus and at necropsy.

CF was confirmed at necropsy. Where faeces were collected, only 2 infants' specimens had a ratio $<4 \cdot 0$. In one, the infant was receiving pancreatic enzyme supplement and, in the other, the infant had been diagnosed early by a sweat test before symptoms became apparent. The sweat test was carried out, despite a negative meconium result, because the infant was known to be at risk. Five of the 9 infants were younger siblings of children with CF. Three of the 4 other infants (Cases 1, 4, and 6) had older normal siblings but all 3 mothers had had previous miscarriages.

Distribution of protease inhibititors in meconium, cord serum, and amniotic fluid. As the protease inhibitors in meconium are resistant to proteolysis, their distribution in meconium should be similar to their distribution in the major source of meconium serum protein whether it is amniotic fluid or vascular transudates. The distributions of protease inhibitors were estimated in 55 normal and $26 \mathrm{CF}$ meconium specimens, in 55 cord sera and 50 amniotic fluids, and the $\alpha$-1-TI: $\alpha-1-\mathrm{CI}$ ratios were calculated (Table 4). The cord sera came from the same neonates as the normal meconium specimens. Although the

Table 4 Distribution of protease inhibitors in meconium cord serum, and amniotic fluid

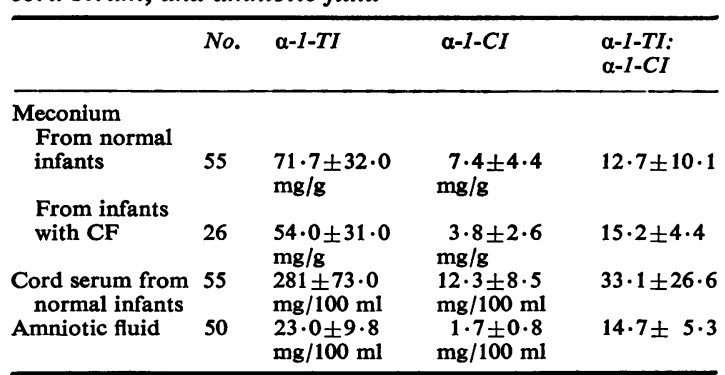

Conversion: traditional units to $S I-\alpha-1$-trypsin inhibitor: $1 \mathrm{mg} / 100 \mathrm{ml}$ $\approx 0.01 \mathrm{~g} / 1$ concentration of the protease inhibitors in meconium from infants with CF was lower than in specimens from normal infants, the proportion of $\alpha-1-$ TI to $\alpha-1-C I$ in the two groups was not significantly different $(P>0 \cdot 2)$. The $\alpha-1-T I: \alpha-1-C I$ ratio in amniotic fluid was similar to that in normal or $\mathrm{CF}$ meconium (in both $P>0 \cdot 2$ ), but the $\alpha-1-\mathrm{TI}: \alpha-1-\mathrm{CI}$ ratio $(33 \cdot 1)$ in cord sera was significantly higher than the ratio in meconium $(\mathrm{P}<0 \cdot 001)$.

The $\alpha-1-$ TI and $\alpha-1-C I$ content was estimated in 2 other meconium specimens not included in the analysis. The 1st was from an infant born to a mother with $\mathrm{ZZ} \alpha-1-\mathrm{TI}$ deficiency in whom the amniotic fluid would also be $\alpha-1-$ TI deficient. The ratio between the 2 protease inhibitors is $1 \cdot 6: 1$. The infant's $\alpha-1-$ TI was typed as MZ and the $\alpha-1-T I$ : $\alpha-1-C I$ in the cord serum was $12 \cdot 8: 1$. The 2 nd specimen was from a child with oesophageal atresia without a tracheo-oesophageal fistula and in whom the specimen was unlikely to have amniotic fluid. The $\alpha-1-T I$ concentration was $6 \mathrm{mg} / \mathrm{g}$ dry weight but only trace amounts of $\alpha-1-C I$ could be detected in a $4 \%$ aqueous extract.

\section{Discussion}

BM mec-test strip compared with albumin immunoassay. There was little difference in specificity between the BM mec-test and the albumin assay. The test strip is quicker and simpler and can be carried out in the wards. However, if it is used by untrained personnel, it is likely that a higher incidence of false-positive results will be obtained than the $0.5 \%$ reported in this investigation. An overall false-positive rate of between 1 and $2.5 \%$ of all specimens screened has been reported (Stephan et al., 1975; Schuttringer and Zinterhofer, 1978).

The albumin electroimmunoassay done in this laboratory gives a quantitative rather than a qualitative result; this result is obtained within half a day rather than the 24-48 hours needed for immuno- 
diffusion. In specimens containing $>20 \mathrm{mg}$ albumin/ $\mathrm{g}$ dry weight, an alb: $\alpha-1-$ TI ratio can be determined in the meconium and subsequent faecal specimens. Such a procedure reduces the false-positive results to a negligible number and, at the same time, confirms positive results. A quantitative albumin estimation may also be combined with limited sweat testing to reduce the number of false-negative results. This suggestion is based on the observation that in this study, 7 of the 9 false-negative specimens contained more than $1 \mathrm{mg}$ albumin/g dry weight. Kollberg and Hellsing (1975) also reported that the 2 false-negative specimens in their study each contained $>1 \mathrm{mg}$ albumin/g dry weight. A sweat test for those infants in whom the meconium contained $>1 \mathrm{mg}$ albumin $/ \mathrm{g}$ dry weight would mean testing about 34 infants in every 1000 live births, and such infants could be tested on their first clinic attendance. A sweat test should be done earlier if the meconium specimen is positive and the ratio remains positive in the stool; it should also be carried out if the child is a sibling of a known case. The high incidence of false-negative specimens from younger siblings of known CF children found in this study means that no reliance should be put on negative meconium test results from such children.

The cost of the 2 tests is difficult to determine because there are so many variables. The cost of material for the albumin immunoassay, provided the antiserum is prepared in the laboratory, is about one-10th that of the material for the BM mec-test; one penny per test compared with 10 pence per test. If commercial antiserum is used the cost of the albumin assay increases almost 3-fold. It is not possible to assess the cost of labour for the 2 tests as the salary of the investigator varies. In our laboratory, the time for testing $\mathbf{1 0}$ specimens by the BM mec-test was 5 min compared with $25 \mathrm{~min}$ for the albumin assay; the time of development of both tests was not included. Thus the labour costs are at least 5-fold higher with the albumin immunoassay and, consequently, the total cost for either test is similar.

Origins of false-positive and negative results obtained with meconium screening. Identification of the source of serum protein and particularly albumin in meconium is important if one is to explain the reasons for false-positive and false-negative results and consequently determine if it is possible to improve the specificity of the test. There is no definite evidence on the major source of albumin and other serum proteins in meconium but the consensus is that most of it comes from ingested amniotic fluid (Schutt and Isles, 1968; Prosser et al., 1974; Ryley et al., 1975), rather than from transudates into the gut from the fetal vascular system. The findings concerning the distribution of inhibitors in meconium, cord serum, and amniotic fluid support this view.

If amniotic fluid is the main source of meconium serum protein, the final concentration of albumin almost certainly reflects pancreatic enzyme activity but if there is a large contribution of protein from the fetus, it could be argued that raised meconium albumin concentrations in CF may reflect an increase in the intestinal transudation (Wiser and Beier, 1964; Rule et al., 1970), especially from the lower part of the gut where proteolytic activity may be less. The results in this study show that serum protein originates from the same source in meconium specimens from healthy neonates and infants with $\mathrm{CF}$, and are consistent with the suggestion that vascular transudates do not contribute substantially to the final protein content of meconium. Thus a raised albumin content in meconium from $\mathrm{CF}$ infants signifies deficient pancreatic enzyme activity in the fetal gut and similarly a false-negative meconium test means that the specimen was passed by an infant with $\mathrm{CF}$ who had normal pancreatic function at birth.

Those infants without $\mathrm{CF}$ who pass meconium with a raised albumin content could have reduced pancreatic function at birth. Gitlin et al. (1972) reported that before birth, a fetus daily ingests half the total volume of amniotic fluid and consequently as amniotic fluid volumes vary, so also does the amount of ingested protein from child to child. Reduced intestinal proteolytic activity coupled with a higher than average protein intake might lead to a final raised meconium albumin content. This would explain why the alb: $\alpha-1-$ TI ratio is effective in reducing false-positive results. The ratio compares the concentration of a protein liable to proteolysis, albumin, with the concentration of a protein resistant to proteolysis, $\alpha-1-\mathrm{TI}$. Thus the concentration of $\alpha-1-T I$ in meconium directly reflects the initial protein intake and will be high or low accordingly. The concentration of albumin, on the other hand, depends not only on its initial concentration but also on the extent of its proteolysis. A high initial albumin concentration together with reduced proteolytic activity may result in a specimen giving a positive albumin result. A specimen from another infant with the same reduced gut enzyme activity but in whom the initial albumin intake was low, may give a negative albumin result. The ratio in both specimens however will be similar.

Contamination by occult blood has been suggested as an alternative explanation for false-positive results, especially in preterm births (Griffiths et al., 1976), because of the observation that many specimens containing albumin also gave a positive guaiac 
test. At the start of our study, we routinely tested $1 \%$ meconium extracts for occult blood with the Hema-Combistix (Ames Company, Bucks, England) which used the o-toluidine-peroxidase reaction for haem. The test was stopped after positive results were obtained with the first 100 specimens, only 2 of which contained any albumin. The specificity of the 2 tests is similar although the test stick is probably more sensitive than the guaiac test (Makarem, 1974). It is therefore not clear at the moment how important contamination by occult blood is in the generation of false-positive results.

\section{CF screening}

This study shows that current meconium tests for CF which appear to depend on the status of pancreatic function will miss about $25 \%$ of infants with the disease. If for any reason CF is suspected, little reliance should be put on a negative meconium test. Also any new test should be assessed according to what effect the presence or absence of proteolytic activity will have on the component being measured, as specificity will be increased only if it can be shown that there are changes in meconium composition caused by the underlying genetic lesion but independent of pancreatic activity. Such changes, if present, will probably be found in the mucin component of meconium.

The final assessment on whether screening for $\mathrm{CF}$ should become routine will depend not only on the specificity of tests but on the results of long-term treatment in cases where this was initiated soon after birth. If a better prognosis is related to early detection, even a test that detects $75 \%$ of affected children will contribute to the management of the disease when linked to a programme of treatment. In our opinion such studies are feasible with current meconium screening methods.

We thank Mrs J. Eady, Mrs G. Burns, and Mrs S. Rees for their technical assistance; the nursing staff of the various Cardiff maternity units for the conscientious collection of specimens; Dr S. Walker of the Department of Obstetrics and Gynaecology, UHW for the specimens of amniotic fluids. This work was supported by a research grant from the Medical Research Council and a grant from Boehringer Mannheim GmbH.

\section{References}

Committee for a Study for Evaluation of Testing for Cystic Fibrosis (1976). Report. Journal of Pediatrics, 88, 711-750. Gitlin, D., Kumate, J., Morales, C., Noriega, L., and
Arevalo, N. (1972). The turnover of amniotic fluid protein in the human conceptus. American Journal of Obstetrics and Gynecology, 113, 632-645.

Griffiths, A. D., Bull, F. E., and Dykes, P. (1976). Effect of gestational length on albumin content in meconium. Archives of Disease in Childhood, 51, 321-323.

Huang, N. N., Macri, C. N., Girone, J., and Sproul, A. (1970). Survival of patients with cystic fibrosis. American Journal of Diseases of Children, 120, 289-295.

Kollberg, H., and Hellsing, K. (1975). Screening for cystic fibrosis by analysis of albumin in meconium. Acta paediatrica Scandinavica, 64, 477-482.

Makarem, A. (1974). In Clinical Chemistry: Principles and Technics, second edition, p. 1123. Edited by R. J. Henry, D. C. Cannon, and J. W. Winkelman. Harper and Row: New York.

Orenstein, D. M., Boat, T. F., Stern, R. C., Tucker, A. S., Charnock, E. L., Matthews, L. W., and Doershuk, C. F. (1977). The effect of early diagnosis and treatment in cystic fibrosis. American Journal of Diseases of Children, 131, 973-975.

Prosser, H., Owen, H., Bull, F., Parry, B., Smerkinich, J., Goodwin, H. A., and Dathan, J. (1974). Screening for cystic fibrosis by examination of meconium. Archives of Disease in Childhood, 49, 597-601.

Rule, A. H., Baran, D. T., and Shwachman, H. (1970). Quantitative determination of water-soluble proteins in meconium. Pediatrics, 45, 847-850.

Ryley, H. C., Neale, L. M., Brogan, T. D., and Bray, P. T. (1975). Screening for cystic fibrosis by analysis of meconium for albumin and protease inhibitors. Clinica chimica acta, 64, 117-125.

Ryley, H. C., Neale, L. M., Prosser, R., and Dodge, J. (1976). Screening for cystic fibrosis by analysis of serum protein in faeces. Archives of Disease in Childhood, 51, 641-643.

Schutt, W. H., and Isles, T. E. (1968). Protein in meconium from meconium ileus. Archives of Disease in Childhood, 43, 178-181.

Schuttringer, G., and Zinterhofer, L. (1978). Automated immunoprecipitation of meconium albumin for cystic fibrosis screening in the newborn. Clinica chimica acta, 83, 109-116.

Shwachman, H., Redmond, A., and Khaw, K. T. (1970). Studies in cystic fibrosis. Report of 130 patients diagnosed under three months of age over a 20-year period. Pediatrics, 46, 335-343.

Stephan, U., Busch, E. W., Kollberg, H., and Hellsing, K. (1975). Cystic fibrosis detection by means of a test strip. Pediatrics, 55, 35-38.

Stern, R. C., Boat, T. F., Doershuk, C. F., Tucker, A. S., Primiano, F. P., and Matthews, L. W., (1976). Course of cystic fibrosis in 95 patients. Journal of Pediatrics, 89, 406-411.

Warwick, W. J. (1969). Respiratory complication of cystic fibrosis. Minnesota Medicine, 52, 1567-1569.

Wiser, W. C., and Beier, F. R. (1964). Albumin in the meconium of infants with cystic fibrosis: a preliminary report. Pediatrics, 33, 115-119.

Correspondence to Dr H. C. Ryley, Welsh National School of Medicine, Department of Medical Microbiology, Heath Park, Cardiff CF4 4XN.

Received 5 April 1978 